\section{How it all happened}

\section{Genes, Peoples, and Languages \\ by Luigi Luca Cavalli-Sforza (translated by Mark Seielstad)}

North Point Press, Farrar, Strauss and Giroux, \$24, ISBN 0-86547-529-6, 2000 Reviewed by Mark Stoneking

Max Planck Institut for Evolutionary Anthropology, Leipzig, Germany

Once upon a time, a Neolithic man named Tegumai and his daughter Taffy were spearing fish for dinner, when Tegumai broke his spear. Having neglected to bring a spare, and being too far from the village for Taffy to run back to fetch another, Tegumai went about repairing the broken one. Meanwhile, a Stranger-man, who spoke a different language, came up to Taffy, so she commenced to scratch out a picture on a piece of bark, illustrating her father's need for another spear. To emphasize the point, she included lots of spears in the drawing. The Stranger-man interpreted the child's drawing as indicating that Tegumai was in imminent danger of attack (surrounded, as he was, by spears in the drawing) and wanted reinforcements, so the Stranger-man hurried off to the village with the picture.

The villagers interpreted the drawing as indicating that the Stranger-man had killed Tegumai (all those spears, you know), but before chopping off the Stranger-man's head, they took him to the river so he could show them what he had done with Taffy. The villagers were quite surprised to find Tegumai alive and well and spearing fish with his newly repaired spear; Taffy was quite surprised (and annoyed) at the way the Stranger-man had been mistreated; and Tegumai was quite surprised to find the entire village descending upon him, ruining his fishing for the rest of the day. But soon everything was sorted out and put right, the Strangerman cleaned up and made an honorary member of the village, and Taffy was congratulated for her great idea of drawing a picture to communicate information (never mind that the message wasn't properly understood by anyone). And that's how writing was invented.

Maybe it didn't really happen that way, but Kipling's How The First Letter Was Written is nonetheless great fun. More to the point, when it comes to investigating our evolutionary past, we often resort to telling stories because human evolution is a historical science-hypotheses cannot be tested by direct experimentation. Luigi Luca Cavalli-
Sforza acknowledges this oxymoronic nature of historical science in the preface to his new book Genes, Peoples, and Languages, but then goes on to suggest a way around this difficulty. Namely, the information one gleans from different disciplines (in particular, genetics, archaeology and linguistics) is tantamount to independent verification. So Cavalli-Sforza adopts a multidisciplinary approach for explaining to a lay audience the past 100,000 years of human evolution in six succinct chapters. And when it comes to reconstructing human evolution, with a career spanning the past half-century, no one commands the same grasp of genetics, archaeology and linguistics (with some demography and cultural anthropology thrown in for good measure) as Cavalli-Sforza.

The first chapter trots out the usual genetic arguments against racism: that gene frequencies change in a continuous manner across populations (rendering racial classification arbitrary), and that even the smallest, most isolated population has about $85 \%$ of the genetic variation present in the entire world population (so racial differences are only skin-deep and do not extend to the majority of our genes). Whereas Cavalli-Sforza presents these arguments eloquently, I must confess that these 'biological' arguments against racism make me uncomfortable. Suppose, instead, that there were deep and highly significant genetic differences among the world's populations: would that now justify claims of superiority by one group over another, or maltreatment of one group by another? Surely the answer is no. How humans treat one another (and other species) is a matter of morality, not biology.

The next two chapters set the stage for what is to come: introducing the main genetic players (protein markers, mtDNA, Y-DNA, microsatellites) and methods of analysis (genetic distances, trees, principal components), as well the forces influencing genetic variation, such as selection and migration. 'Mitochondrial Eve' and 'Y-DNA Adam' are also touched upon here, as are other events in human evolution that occurred more than 100,000 years ago. This is done in a clear and straightforward manner.

The fourth and fifth chapters are the meat of the book, dealing with the migrations of modern humans over the past 100,000 years and the relationship between genetic and linguistic variation. This is Cavalli-Sforza at his best; no one else has the intellectual depth and breadth to marshal archaeological, genetic and linguistic information in such impressive fashion, detailing human migrations from the Neolithic expansion of farmers across Europe to the Greek colonization of 1000 B.C. And no one else has so provocatively argued for a close correspondence between the genetic and linguistic relationships of populations, although I do wonder to what extent this close correspondence is due to the confounding effect of geography.

The final chapter presents a less wellknown aspect of Cavalli-Sforza's work, concerning cultural innovation, transmission and evolution. Geneticists not familiar with these ideas will find this fascinating. For example, there are similarities between biological and cultural evolution-both involve the independent processes of mutation or innovation, followed by a spread through the population-as well as differences, such as horizontal transmission in cultural evolution and 'directed innovation'. It is particularly refreshing that Cavalli-Sforza ends with a plea for further study of cultural variation and evolution as a means of reducing the 'diseases', such as poverty, racism, drug addiction and crime, that afflict society. In this age of the over-hyped Human Genome Project as the solution to all of our problems, rare indeed is the geneticist who will admit that there might be anything to be learned from the social sciences.

The great strength of Genes, Peoples, and Languages - the richly detailed migrations that are revealed by the gene geography maps, for which the supporting archaeological and linguistic evidence is laid outis also its main weakness. No matter how convincing a case can be made for a particular scenario, such as the correspondence between the first principal component in the European gene map and the spread of agriculture from the Near East, it all boils down to storytelling. The first principal component of European genes may indeed reflect a Neolithic expansion of farmers, but it might also reflect a Paleolithic or other expansion, and the correlation with the spread of agriculture may be merely a coincidence. But that should not deter anyone from reading this book. Human evolution is full of great stories, and nobody tells them better than Cavalli-Sforza. Just remember, maybe it really happened that way-and maybe it didn't. 